\title{
Hubungan Antara Hepatotoksisitas dengan Usia, Status Gizi, dan Lama Pemberian Asam Valproat pada Anak Epilepsi
}

\author{
Siti Aurelia Nurmalasari, Elisabeth S. Herini, Nenny Sri Mulyani \\ Bagian Ilmu Kesehatan Anak, Fakultas Kedokteran Universitas Gadjah Mada/RSUP. Dr. Sardjito, \\ Yogyakarta
}

Latar belakang. Epilepsi masih merupakan penyakit yang banyak diderita masyarakat di seluruh dunia. Limapuluh juta orang diperkirakan menderita epilepsi di seluruh dunia dengan angka insiden tahunan berkisar 20-70 kasus per 100000 penduduk, dan angka prevalensi 0,4\%-0,8\%. Prevalensi epilepsi yang tinggi secara langsung akan berimbas penggunaan asam valproat tinggi, dan dapat meningkatkan risiko dampak hepatotoksisitas.

Tujuan. Mengetahui hubungan antara usia, status gizi, lama terapi dengan kejadian hepatotoksisitas pada anak epilepsi yang mendapatkan terapi asam valproat.

Metode. Penelitian desain potong lintang. Data diambil pada bulan September - November 2011 di RSUP DR. Sardjito, Yogyakarta. Kriteria inklusi adalah anak epilepsi usia $<18$ tahun yang mendapat terapi asam valproat paling sedikit 3 bulan di Poliklinik Rawat Jalan, serta bersedia mengikuti penelitian. Kriteria eksklusi adalah anak yang menderita penyakit hati sebelumnya. Data diolah menggunakan korelasi Pearson dan Spearman.

Hasil. Tidak ada hubungan antara usia, status gizi, lama terapi dengan hepatotoksisitas yang ditandai dengan peningkatan kadar ALT pada anak epilepsi yang menggunakan asam valproat $(r=-0,009, p=0,946$; $\mathrm{r}=-0,198, \mathrm{p}=0,136$ dan $\mathrm{r}=0,009, \mathrm{p}=0,947)$.

Kesimpulan. Usia, status gizi, dan lama terapi tidak berhubungan dengan hepatotoksisitas pada anak epilepsi yang mendapatkan terapi asam valproat. Sari Pediatri 2013;15(3):186-9.

Kata kunci: epilepsi pada anak, usia, status nutrisi, lama terapi, asam valproat, hepatotoksisitas

\section{Alamat korespondensi:}

Dr. Siti Aurelia Nurmalasari, Bagian Ilmu Kesehatan Anak, Fakultas Kedokteran Universitas Gadjah Mada/RSUP. Dr. Sardjito, Jalan Kesehatan No. 1 Sekip Yogyakarta 55284, Indonesia. Telp. (0274) 561616, Fax. (0274) 583745. E-mail: aurelia.upa@gmail.com

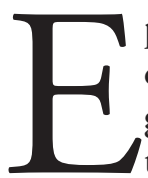

pilepsi merupakan penyakit yang banyak diderita masyarakat diseluruh dunia. Secara global diperkirakan 2,4 juta kasus baru setiap

tahun, dan 50\% kasus terjadi pada masa kanak-kanak atau remaja. Insiden tertinggi terjadi pada masa kanak-kanak, kemudian menurun pada usia 1565 tahun, dan naik lagi pada geriatri. ${ }^{1}$ 
Asam valproat (valproic acid $=$ VPA) adalah salah satu obat anti epilepsi yang sering digunakan di seluruh dunia, dan menurut literatur banyak efek samping yang perlu didiskusikan selain dari efek terapi. ${ }^{2}$ Hepatotoksisitas akibat valproat secara histologis berupa steatosis mikrovaskular (1:20 000) pasien. Namun demikian, insiden lebih tinggi pada pasien usia $<2$ tahun (1:600-1:800) dengan kejang yang parah, kelainan neurologis, kerusakan otak, dan retardasi mental untuk anak yang menerima politerapi. ${ }^{3,4}$ Beberapa defek kongenital enzim mitokondria yang berkaitan dengan fatty acid oxidation (FAO) dan oxidative phosphorylation (OXPHOS) ditemukan pada kasus hepatotoksik akibat VPA. ${ }^{5}$

\section{Metode}

Rancangan penelitian potong lintang dilaksanakan pada bulan September 2011 sampai November 2011 di poliklinik Neurologi Anak RSUP Dr. Sardjito, Yogyakarta. Subyek penelitian adalah anak epilepsi yang mendapatkan terapi VPA tunggal. Kriteria inklusi, yaitu anak usia $<18$ tahun, telah mendapatkan monoterapi asam valproat paling sedikit selama 3 bulan dan persetujuan orang tua/wali. Kriteria eksklusi adalah anak dengan penyakit hati sebelumnya. Perhitungan besar sampel tunggal minimal pada uji hipotesis dengan menggunakan koefisien korelasi (r), dengan besar sampel minimal $53 .{ }^{6}$ Korelasi antara variabel dependen dengan kadar alanin aminotransferase (ALT) dinilai menggunakan korelasi Pearson dan Spearman. ${ }^{7}$

Penelitian ini telah disetujui oleh Komisi Etik Penelitian Kedokteran dan Kesehatan Fakultas Kedokteran Universitas Gadjah Mada.

\section{Hasil}

Dari 58 subyek penelitian didapatkan laki-laki 36 $(62 \%)$ dan perempuan $22(38 \%)$ dengan rerata 7,4 tahun $( \pm 3,5 \mathrm{SD})$, berkisar dari 1 tahun sampai 14 tahun yang mendapatkan terapi asam valproat. Lama penggunaan asam valproat berkisar dari 4 bulan sampai 60 bulan dengan rerata 24 bulan $( \pm 14,3 \mathrm{SB})$. Kadar ALT seluruh subyek berkisar antara 11-42 mg/ dL dengan rerata SB $(19,9 \pm 4,6)$. Karakteristik dasar subyek tertera pada Tabel 1 .

Hasil uji korelasi menunjukkan tidak terdapat hubungan antara usia, status gizi, lama terapi dengan hepatotoksisitas yang ditandai dengan peningkatan kadar ALT pada anak epilepsi yang menggunakan asam valproat $(\mathrm{r}=-0,009, \mathrm{p}=0,946 ; \mathrm{r}=-0,198, \mathrm{p}=0,136$ dan $\mathrm{r}=0,009 ; \mathrm{p}=0,947)$. (Gambar 1$)$.

Hasil tersebut perlu dicermati karena subyek usia $\leq 2$ tahun berjumlah sedikit dibandingkan dengan usia yang lebih tua. Kemungkinan pemberian asam valproat pada kelompok umur yang lebih muda lebih sedikit dibandingkan kelompok umur yang lebih tua karena pertimbangan keamanan obat (hepatotoksik). Hubungan hepatotoksisitas yang ditunjukkan dengan kadar ALT dengan lama terapi menunjukkan bahwa tidak terdapat hubungan antara usia dengan hepatotoksisitas (Gambar 2).

Pada scatter plot tertera bahwa pasien yang menggunakan asam valproat baik dalam jangka waktu pendek atau panjang tidak terdapat peningkatan ALT yang menunjukkan terjadinya hepatotoksisitas.

Tabel 1. Karakteristik dasar subyek

\begin{tabular}{lcr}
\hline Variabel & Rerata (SB) & $\mathrm{n}(\%)$ \\
\hline Jenis kelamin & & \\
$\quad$ Laki-laki & & $36(62)$ \\
$\quad$ Perempuan & & $22(38)$ \\
Umur (tahun) & $7,4(3,5)$ & \\
$\quad \leq 2$ & & $3(5)$ \\
$\quad>2$ & & $55(95)$ \\
Status gizi & & $1(1,7)$ \\
$\quad$ Buruk & & $5(8,6)$ \\
$\quad$ Kurang & & $52(89,7)$ \\
$\quad$ Baik & & \\
Lama terapi & & \\
Kadar ALT & $23,9(14,3)$ & \\
\hline
\end{tabular}

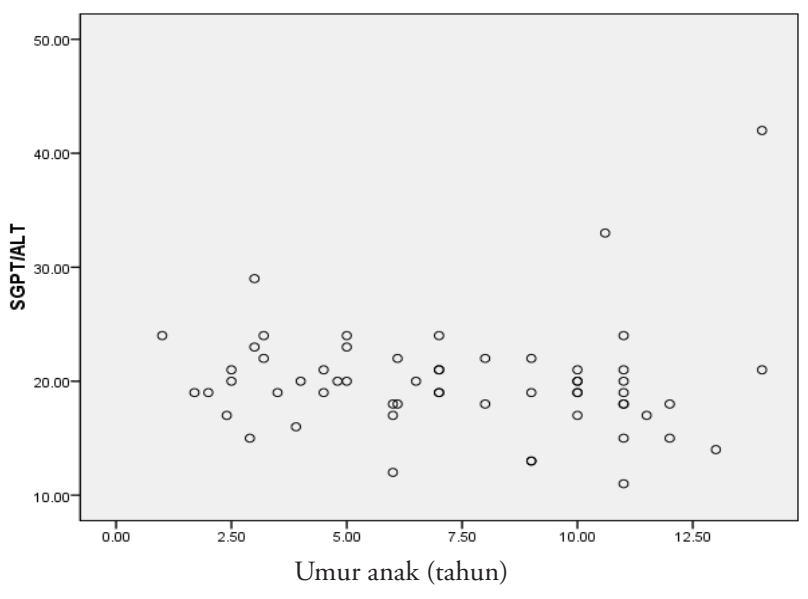

Gambar 1. Scatter plot kadar ALT berdasarkan umur anak 


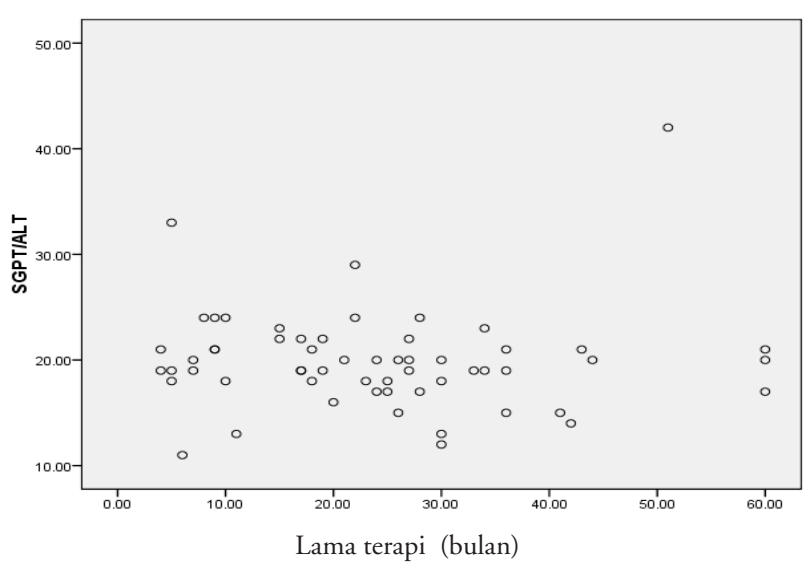

Gambar 2. Scatter plot kadar ALT berdasarkan lama terapi

\section{Pembahasan}

Hasil pemeriksaan kadar ALT menunjukkan 1 subyek dengan kadar ALT yang tinggi (ALT $=42)$, tetapi kadar tersebut tidak bermakna. Hal tersebut menunjukkan kerusakan hepatosit karena kenaikan tidak mencapai dua kali atau lebih dari nilai normal. Angka prevalensi peningkatan ALT 0,017\%, sesuai dengan laporan Jackson $\mathrm{dkk}^{8}$ yang menyatakan insiden abnormalitas ALT pada pemberian asam valproat $0 \%-44 \%$, dan sebagian besar tidak bergejala.

Menurut literatur, terjadinya peningkatan ALT dua kali normal menjadi penanda kerusakan sel he$\operatorname{par}^{9}$ dan harus menjadi perhatian khusus bagi klinisi akan terjadinya penyakit hati yang menyertai. Jika pada follow up lanjutan didapatkan peningkatan yang progresif maka harus dipikirkan tentang penghentian obat tersebut dan penggantian dengan obat anti epilepsi yang lain. ${ }^{1,3}$

Mekanisme terjadinya hepatotoksisitas oleh asam valproat tampaknya meliputi perubahan menjadi metabolit yang toksik, kelainan metabolik, dan faktor predisposisi yang menyebabkan individu rentan terjadi hepatotoksik terhadap obat tertentu. Namun, mekanisme pasti belum diketahui dengan jelas. ${ }^{10}$ Faktor risiko yang diduga berhubungan dengan gagal hati akibat valproat adalah usia muda, retardasi mental, riwayat gangguan metabolik atau inborn errorr of metabolism, polifarmasi, kondisi yang menimbulkan stres seperti infeksi, dan penyakit hati yang mendasari. $^{3,11,12}$

Pasien epilepsi dengan gizi kurang atau buruk jumlahnya lebih sedikit dibandingkan dengan pasien epilepsi dengan gizi baik. Hal tersebut kemungkinan disebabkan kenaikan berat badan akibat pemakaian asam valproat, tetapi tidak dapat dibuktikan pada penelitian kami karena pemeriksaan berat badan hanya dilakukan satu kali. Abaci dkk ${ }^{13}$ menyatakan terdapat hubungan yang bermakna antara BMI saat 6 bulan terapi dengan kadar VPA serum.

Pada scatter plot yang menggambarkan hubungan kadar ALT dengan lama terapi terlihat bahwa pasien pengguna asam valproat baik dalam jangka waktu pendek atau panjang tidak menunjukkan peningkatan ALT yang menggambarkan terjadinya hepatotoksisitas. Hasil penelitian kami berbeda dengan penelitian Attilakos dkk $^{14}$ yang menyatakan kadar ALT setelah pemakaian monoterapi asam valproat selama 6 dan 12 bulan menunjukkan peningkatan yang bermakna secara statistik. Peneliti lain mencari hubungan antara faktor-faktor risiko asam valproat (usia muda, polifarmasi, dan kadar asam valproat yang tinggi) dalam serum menunjukkan ketiga faktor risiko tersebut meningkatkan perubahan asam valproat menjadi metabolit 4-en/VPA yang toksik terhadap hepar. ${ }^{15}$

Hubungan antara pemberian asam valproat dengan penanda stres oksidatif menunjukkan bahwa anak yang diterapi dengan asam valproat mempunyai kadar $15-\mathrm{F}_{2 \mathrm{t}}$-IsoP yang tinggi dibandingkan dengan kelompok plasebo dan obat anti epilepsi yang lain. Hal tersebut mendukung teori bahwa stres oksidatif berhubungan dengan hepatotoksisitas yang berhubungan dengan pemberian asam valproat. ${ }^{16}$

Penelitian Saruwatari $\mathrm{dkk}^{17}$ mengenai hubungan polimorfisme superoxide dismutase 2 (SOD2) val16ala dengan risiko peningkatan enzim aminotransferase akibat VPA menunjukkan bahwa genotipe SOD2 $\mathrm{val} / \mathrm{val}$ merupakan faktor risiko peningkatan enzim amino transferase pada pemberian asam valproat. Sehingga pasien tersebut harus dilakukan monitor fungsi hepar apabila menggunakan asam valproat jangka panjang.

Perbedaan hasil penelitian kami dengan penelitian lain disebabkan oleh perbedaan metode dan besar sampel juga kemungkinan karena peran faktor genetik dalam mekanisme hepatotoksisitas. Kelemahan penelitian kami adalah keterbatasan waktu dan biaya sehingga pemeriksaan kadar ALT hanya dilakukan satu kali, serta tidak dilakukan pemeriksaan penunjang lain untuk menyingkirkan kelainan hepar. Pemeriksaan metabolit asam valproat serum dan polimorfisme genetik tidak dilakukan karena fasilitas pemeriksaan tersebut di institusi kami belum tersedia. 


\section{Kesimpulan}

Usia, status gizi, dan lama terapi tidak berhubungan dengan hepatotoksisitas yang ditandai dengan peningkatan kadar ALT pada anak epilepsi yang mendapatkan terapi asam valproat.

\section{Daftar pustaka}

1. World Health Organization. Sodium valproat in childhood epilepsy, 2006. Diakses tanggal 25 Mei 2008. Didapat dari:http://www.who.co.id.

2. Chateauvieux S, Morceau F, Dicato M, Diederich M. Molecular and therapeutic potential and toxicity of valproic acid. J Biomed Biotechnol 2010:1-18.

3. Ahmed SA, Siddiqi ZA. Antiepileptic drugs and liver disease. Seizure 2006;15:156-64.

4. Guerrini R. Valproate as a mainstay of therapy for pediatrics epilepsy. Pediatr Drug 2006;8:113-29.

5. Begriche K, Massart J, Robin MA, Borgne-Sanchez A, Fromenty B. Drug Induced toxicity on mitochondria and lipid metabolism: mechanistic diversity and deleterious consequences for the liver. J Hepatol 2011;54:773-94.

6. Sastroasmoro S, Ismael S. Dalam: Dasar - dasar metodologi penelitian klinis. Edisi kedua. Jakarta: CV Sagung Seto; 2002.h.97-108.

7. Dahlan S. Statistika untuk kedokteran dan kesehatan, seri evidence based medicine, seri 1. Jakarta: PT Arkans Entertaniment and Education in Harmony;2004.h.155-62.
8. Jackson P, Tredger JM, Williams R. Hepatotoxicity to sodium valproate: a review. Gut 1984;25: 673-81.

9. Amacher DE. Serum transaminase elevations as indicators of hepatic injury following the administration of drugs. Reg Toxicol Pharmacol 1998;27:119-30.

10. Klee S, Johanssen S, Ungemach FR. Evidence for a trigger function of valproic acid in xenobiotic-induced hepatotoxicity. Pharmacol Toxicol 2000;87:89-95.

11. Dreifuss FE, Santili N, Langer DH.Valproic acid hepatic fatalities: a retrospective review. Neurology 1987;37:379-85.

12. Dreifuss FE, Langer DH, Moline KA. Valproic acid hepatic fatalities II. US experience since 1984. Neurology 1989;39:201-7.

13. Abaci A, Saygi M, Yis U, Demir K, Dirik E, Bober E. Metabolic alteration during valproic acid treatment: A Prospective study. Pediatr Neurol 2009;41:435-9.

14. Attilakos A, Voudris, KA, Garoufi A, Mastroyianni S, Dimou S, Prassouli A, Katsarou E, Effect of sodium valproate monotherapy on serum uric acid concentrations in ambulatory epileptic children: a prospective long-term study. Eur J Pediatr Neurol 2006:10:237-40.

15. Kondo T, Kaneko S, Otani K. Associations between risk factors for valproate hepatotoxicity and altered valproate metabolism. Epilepsia 1992;33:172-7.

16. Michoulas A, Tong V, Teng X.W, Chang TK, Abbot FS, Farrel K. Oxidative stress in children receiving valproic acid. J Pediatr 2006;149:692-6.

17. Saruwatari J, Deguchi M, Yoshimori Y. Superoxide dismutase 2 Val16Ala polymorphism is a risk factor for the valproic acid-related elevation of serum amino transferase. Epilepsi Res 2011:1-4. 